Fidei: Jurnal Teologi Sistematika dan Praktika, Vol. 4, No. 2, Des. 2021

Fidei: Jurnal Teologi Sistematika dan Praktika

Terakreditasi No: 85/M/KPT/2020 (Sinta 4)

e-ISSN: $2621-8135$

http://www.stt-tawangmangu.ac.id/e-journal/index.php/fidei

Vol. 4 No.2 (Des. 2021) hlm: 262-279

p-ISSN: 2621-815

Diterbitkan Oleh: Sekolah Tinggi Teologi Tawangmangu

DOI: https://doi.org/10.34081/fidei.v4i2.276

\title{
Pujian dan Penyembahan Sebagai Strategi Pemuridan di Bethany Church Malaysia, Ipoh-Perak
}

\author{
Didimus Sutanto B Prasetya, ${ }^{1}$ Martina Novalina, ${ }^{2}$ Candra \\ Gunawan Marisi, ${ }^{3}$ Joni MP Gultom, ${ }^{4}$ Ronald Sianipar ${ }^{5)^{*}}$ \\ 1) STAKPN Sentani, Indonesia \\ 2) Sekolah Tinggi Teologi Ekumene Jakarta, Indonesia \\ 3,4,5) Sekolah Tinggi Teologi Real Batam, Indonesia \\ *) E-mail: sukardinzeb03@gmail.com
}

Diterima: 04 Sep. 2021 Direvisi: 30 Nov. 2021

Disetujui: 01 Des. 2021

\begin{abstract}
Abstrak
Pekerja Migran Indonesia (PMI) di Ipoh-Perak, Malaysia sebagian besar memiliki masalah multidimensi dari kampung halaman; umumnya mengalami rendah diri, tidak mempunyai cita-cita, umur relatif muda dan miskin akan pengalaman. Tekanan demi tekanan dari lingkungan pekerjaan, masalah ekonomi, pergaulan buruk dan kekuatiran masa depan di negeri asing justru menambah dampak negatif psikologi. Gereja menjadi bagian penting untuk memberikan pendampingan dan kekuatan iman kepada PMI tersebut, gereja mengelola, mengatur dan melibatkan jemaat dalam pelayanan dan menjaga pengajaran yang benar. Penelitian ini bertujuan untuk: (1) mengetahui strategi pentingnya peranan pujian dan penyembahan sebagai strategi pemuridan di BCM Ipoh, Malaysia, (2) mengetahui fungsi pujian dan penyembahan sebagai cara yang berkesinambungan dalam pemulihan gambar diri. Tulisan ini menggunakan penelitian kualitatif deskriptif dengan pendekatan studi pustaka atau literatur. Sebagai hasilnya adalah pujian dan penyembahan dapat menjadi suatu strategi dalam pemuridan yaitu, sebagai pengajaran yang akan menuntun umat kepada pengertian yang benar sehingga menghasilkan respon dan iman kepercayaan (Rom. 10:17). Pujian dan penyembahan memiliki peranan yang penting untuk menyadarkan umat akan posisinya di dalam Kristus dan


menyadarkan akan dosa, sehingga bertobat dan berbalik kepada jalan Tuhan, pengalaman pribadi dengan Tuhan, mendatangkan hadirat Tuhan yang membangun iman, harapan dan kasih sehingga menjadi kunci pembuka dalam memulihkan gambar diri PMI di Malaysia.

Kata-Kata Kunci: Gambar Diri; Pemuridan; Pemulihan; Pujian dan Penyembahan; Strategi.

\section{Abstract}

Indonesian Migrant Workers (PMI) in Ipoh-Perak, Malaysia mostly have multi-dimensional problems from home; generally experience low self-esteem, have no ideals, are relatively young and have poor experience. Pressure after pressure from the work environment, economic problems, bad relationships and worries about the future in foreign countries actually add to the negative psychological impact. The church is an important part to provide mentoring and strength of faith to the PMI, the church manages, regulates and involves the congregation in ministry and maintains true teaching. This study aims to: (1) determine the strategic importance of the role of praise and worship as a discipleship strategy at BCM Ipoh, Malaysia, (2) find out the function of praise and worship as a continuous way of restoring self-image. This paper uses descriptive qualitative research with a literature study approach. As a result, praise and worship can become a strategy in discipleship that is, as teaching that will lead people to the right understanding so as to produce a response and faith (Rom. 10:17). Praise and worship has an important role to make people aware of their position in Christ and awaken to sin, so that they repent and turn to God's way, personal experience with God, brings God's presence that builds faith, hope and love so that it becomes the opening key in restoring self-image. PMI in Malaysia.

Keywords: Discipleship; Praise and Worship; Recovery; Strategy; Self Image.

\section{Pendahuluan}

Pekerja Migran Indonesia (PMI) di luar negeri berasal dari berbagai suku dan tempat di Indonesia dengan latar belakang lulusan SMU sebesar 35,54\%, SMP 39,19\% dan SD 23,57\%. ${ }^{1}$ Dari sekian banyak negara penerima tenaga migran asal Indonesia, Malaysia merupakan negara yang paling banyak dituju oleh tenaga migran asal Indonesia. Hal ini disebabkan oleh beberapa faktor, di antaranya: adanya persamaan budaya dari dua negara serumpun dan juga

\footnotetext{
${ }^{1}$ BP2MI, Data Penempatan Dan Perlindungan PMI Periode Januari 2021 (Jakarta,
} 2021). 
mayoritas kesamaan agama. ${ }^{2}$ Angka pertumbuhan angkatan kerja yang tinggi tidak dibarengi dengan ketersediaan lapangan pekerjaan dan upah yang masih relatif minim di tanah air sehingga terjadi luapan migrasi PMI ke Malaysia ${ }^{3}$, dan tingkat pendidikan dan keahlian yang belum memadai membuat para PMI banyak mengisi sektor pekerjaan yang dikenal 3D (dirty, dangerous and difficult). ${ }^{4} \mathrm{Hal}$ ini membuat masalah yang menimpa PMI di Malaysia semakin meningkat.

PMI non-formal seperti pembantu rumah tangga adalah sektor yang paling rawan menerima masalah; mulai dari perundungan, pelecehan sexual, pemerkosaan dan juga tempat yang tidak layak sering menjadi kasus yang menimpa PMI. ${ }^{5}$ Akbar dalam penelitiannya menunjukkan data kasus permasalahan yang menimpa PMI yang ditangani oleh KBRI di Malaysia pada tahun 2015 adalah sebesar 1.242 kasus baik perdata maupun pidana. Penanganannya sendiri dibagi ke dalam 3 kelompok kategori, yaitu kasus perdata, kasus pidana dan kasus yang terkait non-hukum. ${ }^{6}$ Sedangkan para PMI yang berada di kota Ipoh-Perak, Malaysia sebagian besar berasal dari provinsi Sumatera Utara (peringkat 12) dan NTT (Peringkat 11) sebagai penyumbang terbesar PMI di Ipoh-Perak, Malaysia dengan latar belakang agama adalah Kristen dan Katolik. ${ }^{7}$ Sebagian besar para PMI ini sudah bermasalah dalam hal keuangan, pendidikan dan gambar diri. Umumnya mengalami rendah diri, tidak mempunyai cita-cita, umur relatif muda dan miskin akan pengalaman. Tekanan demi tekanan dari lingkungan pekerjaan, masalah ekonomi, pergaulan buruk dan kekuatiran masa depan di negeri asing menambah dampak negatif psikologi mereka. ${ }^{8}$ PMI dengan tingkat stress yang tinggi, dapat dilihat dari psikologi, fisik dan prilaku yang bermasalah, dan tertuang dalam tindakan yang negatif dan merugikan seperti free sex, kehidupan malam, sex menyimpang seperti $L G B T$, aborsi dan penyalahgunaan narkoba. ${ }^{9}$

Gereja menjadi bagian penting untuk memberikan pendampingan dan kekuatan iman kepada PMI tersebut, gereja mengelola, mengatur dan

${ }^{2}$ Ali Maksum, "Pekerja Migran Indonesia (PMI) Dan Hubungan Indonesia-Malaysia Era Jokowi," Jurnal PIR 2, no. 1 (2017): 1-22.

${ }^{3}$ Suhartoyo Suhartoyo, "Prinsip Persiapan Penempatan Dan Perlindungan Tenaga Kerja Indonesia Di Luar Negeri," Administrative Law and Governance Journal 2, no. 3 (2019): 523540 . Jokowi."

${ }^{4}$ Maksum, "Tenaga Kerja Indonesia (TKI) Dan Hubungan Indonesia-Malaysia Era

${ }^{5}$ Ibid.

${ }^{6}$ Taufan Herdansyah Akbar, Suwarti Sari, and Aliesa Amanita, "Implementasi Kebijakan Pemerintah Dalam Perlindungan Tenaga Kerja Wanita (TKW) Studi Kasus: TKW Di Malaysia," Dinamika Global 2, no. 1 (2017): 23-47.

${ }^{7}$ BP2MI, Data Penempatan Dan Perlindungan PMI Periode Januari 2021.

${ }^{8}$ Joni Gultom and Jemaat BCM Ipoh, Wawancara Tidak Terstruktur (Ipoh, 2021).

${ }^{9}$ Akbar, Sari, and Amanita, "Implementasi Kebijakan Pemerintah Dalam Perlindungan Tenaga Kerja Wanita (TKW) Studi Kasus : TKW Di Malaysia.” 
melibatkan jemaat dalam pelayanan dan menjaga pengajaran yang benar. ${ }^{10}$ Tim misi Gereja Bethel Indonesia telah bekerja sama dengan Bethany Church Malaysia (BCM) Ipoh-Perak Malaysia selama 17 tahun. Jumlah jemaat PMI dua tahun terakhir sekitar 1.000 orang PMI di lima tempat berbeda, yaitu Sitiawan, Taiping, Pengkalan, Silibin dan Klebang Restu. Adapun gambaran demografi dapat dilihat pada tabel berikut ini:

Tabel 1. Demografi Jemaat BCM Ipoh-Malaysia Tahun 2020

\begin{tabular}{|c|c|c|c|}
\hline No & Item & Keterangan & Prosentase \\
\hline \multirow{2}{*}{1.} & \multirow{2}{*}{ Jenis Kelamin } & Wanita & $95 \%$ \\
\hline & & Pria & $5 \%$ \\
\hline \multirow{2}{*}{2.} & \multirow{2}{*}{$\begin{array}{c}\text { Tingkat } \\
\text { Pendidikan }\end{array}$} & SMU & $90 \%$ \\
\hline & & Lainnya & $10 \%$ \\
\hline \multirow{2}{*}{3.} & \multirow{2}{*}{ Usia } & Di bawah 25 Tahun & $75 \%$ \\
\hline & & Di atas 25 Tahun & $25 \%$ \\
\hline
\end{tabular}

Sumber: Wawancara 2021

Berdasarkan tabel di atas terlihat bahwa jemaat BCM Ipoh mayoritas adalah wanita (95\%) dengan rentang usia di bawah 25 tahun, yaitu $75 \%$. Sedangkan tingkat jenjang pendidikan $90 \%$ adalah lulusan SMU. Setelah dilakukan wawancara mendalam kepada beberapa di antara jemaat, didapati bahwa pada umumnya mereka berasal dari latar belakang keluarga yang secara ekonomi bermasalah, ada juga yang mengalami kurangnya tanggung jawab orang tua, sehingga setelah menamatkan pendidikan pada jenjang SMU atau sederajat memutuskan untuk bekerja menjadi tenaga migran di Malaysia. Ratarata tahun bekerja adalah berkisar antara 2-5 tahun, di mana sebagian besar PMI membawa tanggung jawab memikul harapan akan terjaminnya keuangan keluarga. Seperti adanya kiriman finansial untuk orang tua, biaya sekolah untuk adik-adik di kampung bahkan beban tambahan seperti untuk membangun rumah dan masalah lain di kampung menjadi beban tersendiri. ${ }^{11}$

Dalam hal bekerja, para pekerja migran seringkali menghadapi tekanan jam bekerja yang ditetapkan selama 8-12 jam tiap hari dengan tuntutan output yang tinggi dari perusahaan tempat bekerja. Ironisnya tuntutan yang demikian tinggi tidak diimbangi dengan jaminan akan kesehatan para pekerja dari perusahaan. Perusahaan banyak yang mengabaikan kesehatan dan tingkat kejenuhan para pekerja. Waktu libur sering digunakan untuk lembur (overtime) menambah penghasilan dan terkadang memang merupakan suatu kewajiban. Hal ini diperparah dengan kondisi lingkungan tempat tinggal, yaitu rumah maupun

${ }^{10}$ Candra Gunawan Marisi, Didimus Sutanto, and Ardianto Lahagu, "Teologi Pastoral Dalam Menghadapi Tantangan Kepemimpinan Kristen Di Era Post-Modern: Tinjauan Yesaya 40:11," Diegesis: Jurnal Teologi Kharismatika 3, no. 2 (2020): 120-132.

${ }^{11}$ Gultom and Ipoh, Wawancara Tidak Terstruktur. 
hostel yang cenderung melebihi kapasitas, sehingga menimbulkan ketegangan tersendiri di antara para pekerja migran. ${ }^{12}$

Berbagai latar belakang yang menyertai permasalahan para pekerja migran menjadi suatu tantangan tersendiri dalam pelayanan BCM. Pelayanan gereja yang ada guna menjangkau PMI sering mengalami hambatan dan masalah. Masalah yang sering terjadi adalah masalah klasik, yaitu jauhnya jarak gereja dari tempat tinggal sehingga memakan waktu yang tidak sedikit. Banyak yang beribadah karena keterpaksaan, namun tidak sedikit juga yang melupakan ibadah hari Minggu dengan alasan membutuhkan waktu istirahat setelah satu minggu bekerja penuh waktu. Sebagian besar PMI tidak terlalu tertarik dengan segi rohani, disebabkan belum mengalami kehidupan spiritual dengan Tuhan, yaitu mengenal dan mengalami Tuhan. Secara keagamaan mayoritas mereka tercatat sebagai pemeluk Kristen Protestan yaitu, 90\% dan sisanya Katolik dan lainnya adalah $10 \%$. Tetapi mereka tidak mendalami ajaran kekristenan, pemahaman mereka terhadap pengenalan akan Tuhan sangat dangkal. Hal ini terlihat dari tidak tertarik dengan hal-hal rohani, ibadah, baca alkitab dan dari karakter dalam tekanan cenderung reaktif emosional. ${ }^{13}$ Hal ini menunjukkan bahwa pemuridan adalah hal yang diperlukan. Bilangan Research Center mendapatkan bahwa pemuridan sebanyak $80,7 \%$ dinyatakan signifikan memengaruhi pertumbuhan rohani ${ }^{14}$, begitu juga dengan gereja yang memuridkan (>10\% umatnya terlibat dalam pemuridan) umatnya mengalami pertumbuhan lebih tinggi dibandingkan gereja yang hanya 0\%-10\% umatnya terlibat dalam pemuridan. ${ }^{15}$

Pemuridan dapat dilakukan dengan berbagai macam pendekatan. Beberapa penelitian terdahulu menunjukkan hal tersebut. Melben Nainupu dkk, melakukan pemuridan melalui pendekatan dengan 2 aspek penting: (1) aspek berbagi hidup, di mana setiap pondok memiliki mentor dan mentor tersebut hidup bersama mahasiswa; (2) aspek pengajaran, di mana terjadinya proses belajar mengajar secara kelompok dan berdiskusi di kelas pemuridan dan pondokan yang dimulai dengan doa, pujian dan penyembahan, permainan, penyampaian materi berdasarkan Alkitab. ${ }^{16}$ Marthen Nainupu melakukan pemuridan melalui pendekatan konseling pastoral, di mana telah memberikan makna membangkitkan kesadaran kritis terhadap dosa, mewujudkan pemulihan,

${ }^{12}$ Ibid.

${ }^{13}$ Ibid.

${ }^{14}$ Pram, "Pemuridan Mempengaruhi Pertumbuhan Rohani," Berita Bethel.

${ }^{15}$ Handi Irawan D. and Bambang Budijanto, Kunci Pertumbuhan Gereja Di Indonesia Menyingkap Faktor Pendorong Pertumbuhan Gereja Berdasarkan Temuan Survei Nasional $B R C$ (Yayasan Bilangan Research Center, 2021).

${ }^{16}$ Melben Nainupu, Ahmad Tabrani, and Frets Keriapy, "Pemuridan Sebagai Upaya Menanamkan Iman Kepada Kristus Pada Mahasiswa Stak Terpadu Pesat Salatiga," VOX DEI: Jurnal Teologi dan Pastoral 1, no. 2 (2020): 104-117. 
perubahan dan pertumbuhan rohani menuju kepada kedewasaan dalam Kristus. ${ }^{17}$ Daniel Fajar Panuntun dan Eunike Paramita melakukan pendekatan melalui pemuridan kontekstual, yang mana merupakan jawaban atas krisis keteladanan akan kepemimpinan dan upaya untuk mengungkap kaderisasi pemimpin. ${ }^{18} \mathrm{Di}$ antara beberapa penelitian terdahulu tersebut, belum ada yang menekankan tentang pentingnya musik, pujian dan penyembahan sebagai strategi pemuridan dan pemulihan gambar diri orang percaya.

Alasan menggunakan pujian dan penyembahan sebagai strategi pemuridan dikarenakan pola peribadahan di BCM Ipoh mengkolaborasikan pengajaran Firman Tuhan dengan musik dan pujian dan penyembahan sebagai dasar perjumpaan pribadi seseorang dengan Tuhan dan dipenuhi oleh kuasa Roh Kudus (Kis. 16: 25; Kol. 3: 16). Sitepu dalam penelitiannya menyatakan bahwa pendekatan pemuridan yang tepat adalah ketika gereja mampu mendeteksi spiritualitas jemaat berdasarkan tipe-tipenya. ${ }^{19}$ Oleh karena itu, penelitian ini bertujuan untuk: (1) mengetahui strategi pentingnya peranan pujian dan penyembahan sebagai strategi pemuridan di BCM Ipoh, Malaysia, (2) Untuk mengetahui fungsi pujian dan penyembahan sebagai cara yang berkesinambungan dalam pemulihan gambar diri.

\section{Metode Penelitian}

Metode yang digunakan penelitian adalah kulitatif. Dengan pendekatan penelitian kualitatif deskriptif dan pendekatan kajian pustaka atau literatur. ${ }^{20}$ Tahapan yang dilakukan adalah untuk memeroleh hasil yang kualitatif terhadap pandangan teologis mengenai esensi pujian dan penyembahan sebagai strategi pemuridan, dan mengolah data menjadi sebuah penjabaran yang deskriptif.

\section{Pembahasan dan Hasil}

Tim pastoral BCM Ipoh melakukan penjangkauan terhadap PMI dengan pendekatan melalui pujian dan penyembahan di dalam ibadah yang dapat dirasakan oleh jemaat sebagai suatu pengalaman ilahi yang belum pernah dialami sebelumnya, sehingga terdapat kerinduan di dalam hati untuk datang

17 Marthen Nainupu, "Pemuridan Melalui Pendekatan Konseling Pastoral," Jurnal Theologia Aletheia 19, no. 12 (2017): 91-140.

${ }^{18}$ Daniel Fajar Panuntun and Eunike Paramita, "Kaderisasi Pemimpin Melalui Pemuridan Kontekstual Sebagai Jawaban Dari Krisis Keteladanan Kepemimpinan," KINAA: Jurnal Kepemimpinan Kristen dan Pemberdayaan Jemaat 1, no. 1 (2020): 1-15.

${ }^{19}$ Nathanail Sitepu, "Urgensi Menemukan Model Pemuridan Sesuai Tipe Spiritualitas Jemaat," HARVESTER: Jurnal Teologi dan Kepemimpinan Kristen 5, no. 2 (2020): 105-119.

20 Hengki Wijaya, "Metode-Metode Penelitian Dalam Penulisan Jurnal Ilmiah Elektronik," in Strategi Menulis Jurnal Untuk Ilmu Teologi, ed. Sonny Eli Zaluchu (Semarang: Golden Gate Publishing, 2020), 23-42. 
kembali di dalam ibadah selanjutnya. Hal seperti itu dialami oleh jemaat mulamula dalam Kisah Para Rasul pasal 2: 41-42, mereka bertekun dalam pemuridan dan ibadah. Di mana ibadah meliputi pujian penyembahan dan persekutuan. Sepertinya kehidupan ibadah dalam pujian dan penyembahan sangat mewarnai kehidupan jemaat mula-mula, hal ini dapat dilihat dalam pengalaman Paulus dan Silas yang memuji Tuhan ketika di dalam penjara Filipi (Kis. 16: 25).

\section{Pujian dan Penyembahan Sebagai Sarana Perjumpaan Spiritual Yang Mentransformasi}

Pujian dan penyembahan secara spesifik dikatakan oleh Yesus dalam peristiwa Sumur Yakub (Yoh. 4: 1-42). Dalam percakapan dengan perempuan Samaria tersebut, Yesus menekankan bahwa penyembahan bukan berkaitan dengan tempat dan waktu, melainkan hati yang terpusat kepada Allah dalam roh dan kebenaran. Dalam perjumpaan tersebut telah mentransformasi kehidupan perempuan Samaria ini menjadi saksi yang mengabarkan Injil di kotanya. Peristiwa ini menunjukkan kegiatan pemuridan yang dilakukan oleh Yesus dapat memberikan pemahaman yang benar kepada perempuan Samaria tentang pengharapan mereka mengenai penyembahan kepada Allah. Allah itu Roh, sehingga orang harus menyembah Allah dalam roh dan kebenaran. Menyembah dalam roh dan kebenaran adalah penyembahan yang dilakukan oleh seseorang yang telah mengalami kelahiran baru (roh), melalui iman percaya kepada Yesus Kristus (kebenaran). Sehingga penyembahan itu berkaitan dengan hubungan secara pribadi dengan Allah, bukan hanya sekadar musik dan cara bernyanyi tentang Tuhan. ${ }^{21}$ Pemahaman seperti ini dapat terjadi melalui pemuridan yang intens, hal inilah yang mendasari BCM Ipoh Malaysia melakukan pujian dan penyembahan sebagai sarana perjumpaan spiritual kepada jemaat supaya mengalami kehidupan yang diubahkan. Hasil penelitian menunjukkan sebuah data, di mana jemaat BCM Ipoh adalah para PMI yang bekerja di sekitar IpohPerak, Malaysia. Di mana, secara mayoritas bergender wanita $(95 \%)$ dengan rentang usia di bawah 25 tahun, yaitu 75\%. Sedangkan tingkat jenjang pendidikan $90 \%$ adalah lulusan SMU. Setelah dilakukan wawancara mendalam didapati sebuah fakta mengenai latar belakang kehidupan keluarga para PMI tersebut. Adapun kondisi kehidupan latar belakang keluarga PMI di BCM Ipoh Malaysia ditunjukkan pada tabel berikut ini:

21 Firman Panjaitan and Marthin Steven Lumingkewas, "Ibadah Jemaat Kristen Kontemporer Abad 21 Dan Tinjauan Kritis-Liturgis," FIDEI: Jurnal Teologi Sistematika dan Praktika 2, no. 1 (2019): 159-182. 
Tabel 2. Latar Belakang Kehidupan Keluarga Jemaat BCM Ipoh-Malaysia Tahun 2020

\begin{tabular}{|c|c|c|c|}
\hline No & Item & Latar Belakang & Keterangan \\
\hline 1. & $\begin{array}{l}\text { Pekerjaan } \\
\text { orang tua }\end{array}$ & $\begin{array}{l}\text { Keluarga petani } \\
\text { yang sederhana }\end{array}$ & $\begin{array}{l}\text { Kehidupan ekonomi menengah } \\
\text { ke bawah }\end{array}$ \\
\hline 2. & $\begin{array}{l}\text { Pendidikan } \\
\text { orang tua }\end{array}$ & $\begin{array}{l}\text { Rata-rata tidak } \\
\text { sekolah tinggi, } \\
\text { maksimal SMA }\end{array}$ & $\begin{array}{l}\text { Banyak yang tidak memahami } \\
\text { pentingnya Pendidikan }\end{array}$ \\
\hline \multirow{3}{*}{3.} & \multirow{3}{*}{ Kepercayaan } & Protestan $70 \%$ & \multirow{3}{*}{$\begin{array}{c}\text { Rata-rata pemahaman } \\
\text { kerohanian mereka dangkal dan } \\
\text { tidak melek Alkitab }\end{array}$} \\
\hline & & Katolik 25\% & \\
\hline & & Lainnya $5 \%$ & \\
\hline
\end{tabular}

\begin{tabular}{ccc}
\hline Status & Belum menikah & $\begin{array}{c}\text { Tingginya beban tanggung } \\
\text { jawab menafkahi keluarga } \\
\text { membuat mereka belum } \\
\text { memikirkan untuk berumah } \\
\text { tangga }\end{array}$ \\
\hline
\end{tabular}

Sumber: Wawancara 2021

Berdasarkan pada data tabel di atas, didapati bahwa pada umumnya mereka berasal dari latar belakang keluarga yang berekonomi menengah ke bawah, dengan rata-rata berasal dari keluarga petani sederhana, hidup penuh dengan kekurangan secara finansial, dan tidak sedikit yang terjerat masalah hutang piutang. Kurangnya tanggung jawab orang tua, sehingga setelah menamatkan pendidikan pada jenjang SMU atau sederajat harus memikul tanggung jawab keluarga dengan memutuskan untuk bekerja menjadi tenaga migran di Malaysia. Rata-rata tahun bekerja adalah berkisar antara 2-5 tahun, di mana mereka membawa tanggung jawab memikul harapan akan terjaminnya keuangan keluarga. Seperti adanya kiriman finansial untuk orang tua, biaya sekolah untuk adik-adik di kampung bahkan beban tambahan seperti untuk membangun rumah dan masalah lain di kampung halaman. ${ }^{22}$

Bekerja selama 8-12 jam tiap hari menjadi suatu tekanan tersendiri di dalam mengadu nasib di negeri orang. Dalam hal output yang dihasilkan, mereka ditekan dengan tuntutan output yang tinggi dari perusahaan tempat mereka bekerja. Ironisnya hal ini tidak diimbangi dengan jaminan akan kesehatan yang tinggi pula dari perusahaan tempat para PMI bekerja. Selain

${ }^{22}$ Gultom and Ipoh, Wawancara Tidak Terstruktur. 
kesehatan yang tidak diperhatikan oleh perusahaan tempat PMI bekerja, tingkat kejenuhan para pegawai pun tidak diperhitungkan oleh perusahaan. Di mana, untuk menambah penghasilan dan terkadang memang sebagai suatu kewajiban, para PMI dituntut untuk menggunakan waktu liburnya untuk lembur (overtime). Kapasitas rumah ataupun hostel tempat para PMI tinggal adalah cenderung melebihi kapasitas (overload), telah menimbulkan bertambahnya tingkat tekanan stress pada diri mereka. Kondisi kerohanian yang dangkal, etintas sebagai seorang Kristen hanya sebatas agamawi tetapi belum menjelma sebagai kehidupan yang dihidupi secara esensi. ${ }^{23}$ Berbagai perihal tersebut telah membuat para tenaga migran ini tertekan secara psikologis. Dibutuhkan rileksasi akan pentingnya suatu hiburan guna sedikit merehabilitasi kepenatan mereka dari berbagai persoalan.

Hasil berbagai penelitian menunjukkan bahwa musik dapat menjadi alat terapis yang dapat menghadirkan ketenangan, emosi, rileks dan sebagai sarana hiburan. Terapi musik sendiri telah terbukti secara klinis mampu menangani masalah kejiwaan yang berhubungan dengan penyakit ataupun gangguan emosional, kognitif dan juga sosial. Terapi ini membantu seseorang yang kesulitan mengekspresikan diri lewat kata-kata. ${ }^{24}$ Menurut Djohan, terapi musik dapat sangat beragam tergantung pada populasi klien dan dengan siapa para terapis bekerja. Proses terapi difokuskan kepada rehabilitasi dan peningkatan ketrampilan atau peningkatan kemampuan fungsional serta memerbaiki kekurangan yang terjadi pada pengobatan medis pada penderita penyakit kronik tertentu. Terapi musik adalah pemanfaatan kemampuan musik dan elemen musik oleh terapis sebagai sarana perawatan dan peningkatan kesehatan fisik, perbaikan mental, emosional, dan kesehatan spiritual klien. ${ }^{25}$ Hasil penelitian Khoriyah dan Sinaga menunjukkan bahwa pemutaran jenis musik pop dan instrumental bertempo lambat di klinik kesehatan memberikan stimuli positif terhadap pasien berupa rasa rileks, tenang dan nyaman. ${ }^{26}$ Edi Purnomo dkk, dalam penelitiannya menyebutkan bahwa musik dapat menyembuhkan perasaan emosional seseorang seperti, amarah, sedih sehingga musik dapat membawa dampak positif bagi pendengarnya, karena musik dapat mengekspresikan diri sesuai yang diinginkan bahkan dapat memberikan relaksasi pada penderita

${ }^{23}$ Ibid.

${ }^{24}$ Niswati Khoiriyah and Syahrul Syah Sinaga, "Pemanfaatan Pemutaran Musik Terhadap Psikologis Pasien Pada Klinik Ellena Skin Care Di Kota Surakarta," Jurnal Seni Musik 6, no. 2 (2017): 81-90. 27-28.

${ }^{25}$ Djohan Salim, Terapi Musik: Teori Dan Aplikasi (Yogyakarta: Galang Press, 2006).

${ }^{26}$ Khoiriyah and Sinaga, "Pemanfaatan Pemutaran Musik Terhadap Psikologis Pasien Pada Klinik Ellena Skin Care Di Kota Surakarta." 
hipertensi. ${ }^{27}$ Bahkan hasil penelitian Shaleha menyatakan bahwa pengaruh musik tidak bisa dilepaskan dari kehidupan sehari-hari manusia; musik dapat meningkatkan skor IQ seseorang. ${ }^{28}$

Manfaat musik dalam pujian dan penyembahan menjadi komunikasi yang efektif dalam memberikan kontribusi dan solusi dalam memberikan penghiburan, kekuatan dan mentalitas iman untuk memersiapkan mereka kuat bertahan menghadapi tantangan setiap saat. Nainggolan mengatakan bahwa lirik dalam nyanyian lagu rohani harus alkitabiah yang mampu memberi pengajaran tentang sifat-sifat Allah dalam Alkitab sebagai pengajaran kepada yang menyanyikannya maupun pendengarnya. ${ }^{29}$ Oleh sebab itu, nyanyian rohani dapat memberi penghiburan, kekuatan bahkan kesadaran akan pelanggaran dan dosa yang menuntun kepada pertobatan. Sitompul mengklasifisikasikan tujuan musik, pujian dan penyembahan antara lain: memererat hubungan manusia dengan Allah, menerima berkat dari Allah, memerkuat iman, cara memasuki hadirat Allah, dan sebagai jalan melayani Allah. ${ }^{30}$ Hal ini menunjukkan bahwa musik, pujian dan penyembahan memiliki peranan yang penting untuk menyadarkan umat akan posisinya di dalam Kristus dan menyadarkan akan dosa, sehingga bertobat dan berbalik kepada jalan Tuhan sehingga gambar dirinya dapat dipulihkan dan kembali kepada panggilan ilahi, yaitu hidup menjadi berkat bagi orang-orang di sekitar mereka.

\section{Esensi Musik, Pujian dan Penyembahan Sebagai Strategi Pemuridan}

Gereja harus mampu untuk memberikan pengajaran yang alkitabiah. Selain pengajaran dilakukan melalui kelas-kelas khusus dalam serial pemuridan KOM (Kehidupan Orientasi Melayani) dan khotbah, pujian dan penyembahan menjadi salah satu sarana dalam memberikan pengajaran kepada umat. Nainggolan menegaskan bahwa musik gerejawi adalah salah satu unsur yang paling penting dalam teologi. ${ }^{31}$ Selain khotbah, musik pujian dan penyembahan merupakan unsur utama dalam penatalayanan peribadahan kristiani. Rasul Paulus mengajarkan kepada jemaat di Kolose agar melakukan pemuridan dengan hikmat Tuhan serta bersekutu dengan menyanyikan mazmur, puji-pujian dan penyembahan sebagai ucapan syukur kepada Allah (Kol, 3: 16). Itulah sebabnya, musik gerejawi mendapatkan perhatian serius di dalam peribadatan

${ }^{27}$ Edi Purnomo et al., "The Effectiveness of Instrumental Music Therapy and SelfHypnosis on Decreasing Blood Pressure Level among Hypertension Patients," International Journal of Nursing and Health Services (IJNHS) 3, no. 2 (2020): 214-223.

${ }^{28}$ Rinanda Rizky Amalia Shaleha, "Do Re Mi: Psikologi, Musik, Dan Budaya," Buletin Psikologi 27, no. 1 (2019): 43.

${ }^{29}$ Dapot Nainggolan, "Kajian Teologis Terhadap Musik Gerejawi,” Jurnal Luxnos 6, no. 1 (2020): 32-52.

${ }^{30}$ Putra Hendra S. Sitompul, "Musik Dalam Dinamika Pujian dan penyembahan," PNEUMATIKOS: Jurnal Teologi Kependetaan 10, no. 2 (2020): 176-199.

${ }^{31}$ Nainggolan, "Kajian Teologis Terhadap Musik Gerejawi." 
gereja. Musik gerejawi sangat sarat mengandung pengajaran dan tuntunan hidup orang percaya, sehingga lirik-lirik dalam pujian dan penyembahan, serta melodi dan aransemen musiknya pun harus dipadukan secara harmonis, selaras dan seirama dengan Firman Allah. Musik, pujian dan penyembahan bukan hanya berlangsung dalam konteks peribadahan di gereja tetapi harus nyata dan hadir dalam setiap kehidupan keseharian orang percaya. ${ }^{32}$ Hal inilah menjadikan musik, pujian dan penyembahan memiliki esensi dapat menuntun umat untuk melakukan kebenaran Firman Tuhan. Membawa jemaat kepada pemulihan gambar dirinya sesuai dengan esensi kebenaran Firman di dalam Alkitab. Kelahiran baru dalam Kristus akan memulihkan gambar diri sebagai seorang percaya. ${ }^{33}$ Tentu pemulihan gambar diri merupakan sebuah proses yang membawa seorang percaya kepada pembenaran (justification), pengudusan (sanctification) dan pemuliaan (glorification). Penekanan strategi ini adalah dengan ibadah dan pertemuan rohani yang memberikan penekanan pengalaman ilahi melalui musikal ilahi dalam pujian dan penyembahan yang mendalam dan terus diajarkan sebagai sarana pemuridan dalam pemulihan gambar diri.

Tim pastoral BCM Ipoh menjangkau pekerja migran dengan pelayanan dan kekuatan rohani sebagai target utama adalah pemulihan gambar diri di tengah tekanan kehidupan. Sitepu menekankan bahwa pemuridan dilakukan untuk memersiapkan setiap orang yang ada di dalam gereja memiliki karakter seperti Kristus, di mana fokus dan tujuan pemuridan adalah membawa setiap orang mengalami pemulihan hubungan dengan Allah melalui karya salib Kristus, dan kemudian bertumbuh dan semakin menjadi serupa dengan Kristus dalam karakter dan perbuatan. ${ }^{34}$ Musik, pujian dan penyembahan yang dilakukan dalam ibadah di BCM Ipoh menekankan kepada hubungan spiritualitas jemaat kepada Tuhan, di mana jemaat dapat mengekspresikan perasaannya dan pengalaman yang dialaminya dalam kaitannya perjumpaan dengan Tuhan dan jamahan Roh Kudus dalam hidupnya. Seperti yang ditunjukkan pada penelitian Firman Panjaitan bahwa dalam ibadah kaum pentakostal-karismatik, yaitu dalam pujian dan penyembahan, jemaat diajak untuk melampiaskan segala apa yang dirasakan sesuai dengan pujian yang dinaikkan. Ekspresi yang terjadi dalam bernyanyi, jemaat dapat melompat, menari, bersalaman, bertepuk tangan, bersorak karena bersukacita bahkan menangis karena sedih dan meratapi dosa. ${ }^{35}$

Strategi awal adalah membangun Musik, Pujian dan Penyembahan yang berkualitas dalam pelayanan dari tim itu sendiri dengan kualitas kedalaman

32 Ibid.

${ }^{33}$ Candra Gunawan Marisi, "Esensi Kemanusiaan Menurut Gambar Dan Rupa Allah," Real Didache: Jurnal Teologi Dan Pendidikan Agama Kristen 2, no. 2 (2017): 5-33.

${ }^{34}$ Sitepu, "Urgensi Menemukan Model Pemuridan Sesuai Tipe Spiritualitas Jemaat."

35 Panjaitan and Lumingkewas, "Ibadah Jemaat Kristen Kontemporer Abad 21 Dan Tinjauan Kritis-Liturgis." 
menyentuh hati dan kebersamaan. Hengki Wijaya menjabarkan mengenai sikapsikap yang harus dilakukan dalam menyembah Tuhan, di antaranya: sikap hati yang tidak bercabang, sikap hati yang hancur, kerendahan hati, di dasari oleh kasih bukan motivasi yang salah, sikap memberi, sebagai respons atau tanggapan roh seseorang kepada Roh Allah, pertobatan yang membawa kepada kehidupan yang menginjil. ${ }^{36} \mathrm{Hal}$ ini menjadi penting karena gap yang sangat jauh antara panggung dengan jemaat Tuhan. Sudah menjadi rahasia umum bahwa pelayanan musik dijadikan sebagai panggung unjuk kemampuan diri. Pujian dan penyembahan hanya sekadar seni tanpa aksi, seni tanpa solusi. ${ }^{37}$ Musik itu sendiri terdiri dari 9 unsur yang harus diperhatikan agar maksimal, seperti melodi, birama, irama atau ritme, tempo, tangga nada, harmoni, timbre, dinamika dan ekspresi. ${ }^{38}$ Metode pendekatan pribadi dan mengambil beban menjadi kunci untuk para praktisi dan pengguna. Hengki mengatakan bahwa penyembahan itu sebagai role model untuk dapat "berjumpa" dengan Allah. ${ }^{39}$ Musik di sini harus bersifat ilahi dan bernuansa kepada kekekalan meskipun dibawakan dalam keniscayaan sehingga jemaat mengalami suatu pengalaman spiritual, perjumpaan pribadi dengan Tuhan yang mentransformasi pada pembaharuan cara berpikir (Rom. 12:2) yang menuntun kepada iman yang melahir barukan (Ef. 4:23-24; 2 Kor. 5:17) sehingga memiliki suatu pengharapan yang baru dalam melakukan pekerjaan baik (Ef. 2:10).

\section{Pemulihan Gambar Diri Kembali Kepada Tujuan Ilahi}

Rasul Paulus menuliskan bahwa setiap orang percaya adalah pribadi yang telah dipulihkan dan dilahirkan kembali untuk kembali kepada tujuan ilahi yaitu melakukan pekerjaan baik yang dipersiapkan Allah sebelumnya (Ef. 2: 8-10). Melalui pengertian tersebut, tim pastoral membentuk pengajaran secara masif untuk membuka paradigma mereka supaya berubah. Bagaimana seni dengan pengajaran alkitab dapat mengubahkan hati manusia untuk jujur dan mengambil langkah pemulihan rohani tahap demi tahap. Nugroho menyatakan bahwa pemuridan sebagai bentuk Amanat Agung adalah untuk memberikan pertumbuhan kualitas iman menuju kedewasaan rohani. ${ }^{40}$ Menurut Putu

${ }^{36}$ Hengki Wijaya, "Kajian Teologis Tentang Penyembahan Berdasarkan Injil Yohanes 4:24,” Jurnal Jaffray 13, no. 1 (2015): 77.

${ }^{37}$ Bigman Sirait, "Ritual Tanpa Spritual," Reformata.

${ }^{38}$ Ade Endy Arlansyah, "Analisis Bentuk Dan Variasi Melodi Symphony No.9 In E Minor IV: Allegro Con Fuoco Karya Antonin Dvorak,” Repertoar 1, no. 2 (2021): 226-245.

${ }^{39}$ Wijaya, "Kajian Teologis Tentang Penyembahan Berdasarkan Injil Yohanes 4:24."

${ }^{40}$ Yahya Fajar Edhi Nugroho, Yanto Paulus Hermanto, and Rubin Adi Abraham, "Program SMK ( Saya Murid Kristus ) Sebagai Pendekatan Yang Menguatkan Panggilan Dalam Amanat Agung Di Gbi Bethel Bandung," Setiadharma: Journal PKM 1, no. 44-52 (2020). 
pemuridan itu adalah tindakan gereja untuk pergi dan memberikan kualitas yang sama ke tempat lain. ${ }^{41}$

Gereja dan tim pastoral harus berada dalam pengurapan dan kuasa supranatural dalam memulihkan gambar diri jemaat melalui musik, pujian dan penyembahan. Hal ini tidak boleh disimpulkan dalam satu kegiatan atau satu ibadah KKR, namun berada dalam jam-jam yang berkelanjutan dan berkesinambungan yang penuh dengan kebenaran dan akhirnya memulihkan sikap, karakter dan pola pikir jemaat menjadi baru.

Metode yang digunakan adalah dalam ibadah raya Minggu, komunitas sel, pertemuan pertemuan doa yang rutin diadakan seminggu 2 kali bersama-sama, dan saat teduh. Jemaat sangat tersentuh dengan alunan musik dengan lagu-lagu rohani yang menyentuh hati nurani. Awalnya musik, pujian dan penyembahan perlu sosialisasi untuk dapat diterima. Bagaimana harus bersyukur di saat letih dan kecewa, berbahagia di saat tertekan dan kuatir. Musik dan lagu pujian dan penyembahan mendatangkan hadirat Tuhan nyata sehingga jemaat mengalami kekuatan, kebangunan iman. Jemaat mulai serius dan mengikuti dengan membuka hati, membuka mulut untuk menyanyi menyembah dan merespon dengan panca indera dengan maksimal. Awalnya mereka menangis dan hancur hati karena beratnya tantangan kehidupan. Namun seiring dengan strategi musik pujian dan penyembahan dan Firman Tuhan yang terus menerus, membuat mereka nyaman dan menjadi pola kehidupan yang membangun. Penggunaan smartphone menjadi salah satu penghubung strategi ini ke dalam kehidupan mereka sehari-hari. Mengunduh lagu-lagu pujian dan penyembahan, menghapal dan menyanyikan lagu rohani setiap hari, sehingga hati dan pikiran tetap terpaut kepada Tuhan. Aplikasi video singkat dalam media sosial mereka pelajari dan membuat konten-konten sederhana berisi nilai-nilai kebenaran disajikan dalam narasi dengan background lagu rohani dan dibagikan ke rekan sahabat bahkan ke publik melalui media sosial.

Pemulihan gambar diri tidak didapatkan dalam durasi waktu yang singkat, namun memerlukan waktu relatif panjang dengan kualitas dan kuantitas yang terjaga dengan baik. Gembala dan tim pujian dan penyembahan saling melengkapi dan mendukung satu dengan yang lain untuk mendatangkan suasana Ilahi yang dapat dinikmati. Seperti penelitian Telaumbanua menyatakan bahwa selain tanggung jawab dalam penggembalaan, gembala sidang juga bertanggungjawab dalam mendidik, mengajar dan membawa jemaat Tuhan kepada pertumbuhan rohani yang maksimal dan menjadikan jemaat mengerti tentang nilai-nilai kehidupan, sehingga kehidupan bersama segenap anggota gereja dapat terpelihara dengan baik. Dalam hal ini, di mana jemaat mengalami

${ }^{41}$ I Putu Ayub Darmawan, "Jadikanlah Murid: Tugas Pemuridan Gereja Menurut Matius 28:18-20," Evangelikal: Jurnal Teologi Injili dan Pembinaan Warga Jemaat 3, no. 2 (July 2019): 144 . 
pemulihan gambar diri menuju keserupaan dengan Kristus Yesus secara sempurna. ${ }^{42}$

Beberapa tanda pemulihan gambar diri yang terjadi kepada diri jemaat PMI di BCM Ipoh-Perak, Malaysia karena Musik, Pujian dan Penyembahan: Pertama, kelahiran baru-Baptisan Air. Mereka yang membuka hati untuk Tuhan bekerja memberi diri untuk dibaptis. Rata-rata setiap tahun tercatat sekitar 100 jiwa (data per 2010-2019). BCM Ipoh termasuk ke dalam jemaat dengan tipe spiritualitas yang sangat menekankan aspek pengalaman spiritual seperti baptisan Roh Kudus (disertai dengan tanda awal berbahasa roh), kesembuhan ilahi, kelepasan dari ikatan roh-roh jahat, dan praktik karunia nubuat, serta karunia-karunia rohani lainya. ${ }^{43}$ Setelah dibaptis air, orang percaya harus mengimani dan melangkah untuk menerima baptisan Roh Kudus, di mana menurut Sumiwi, perbedaan baptisan air dan baptisan Roh Kudus adalah bahwa baptisan air merupakan pernyataan iman (segi manusia). Orang Kristen mengimani bahwa pada saat dibaptis mereka menjadi satu bagian keluarga kerajaan Allah dan menjadi pribadi yang diselamatkan Tuhan. Ini merupakan bukti bahwa ia sudah di dalam Kristus, sedangkan baptisan Roh Kudus adalah sebagai penyataan anugerah Allah. Selanjutnya adalah hidup dipenuhi oleh Roh, seorang Kristen yang tidak dipenuhi oleh Roh adalah seorang Kristen yang "kering". 44 Kedua, tingkat respon kedalaman akan kuasa Pujian dan Penyembahan yang membawa mereka hormat dan taat saat Firman Tuhan diperdengarkan. Penggunaan smartphone untuk merekam pelayanan dan kotbah memberikan kemudahan untuk mengulang kembali di hari-hari kemudian. Dakhi menegaskan bahwa nilai-nilai rohani yang terkandung di dalam pujian dan penyembahan adalah ketaatan dalam melakukan Firman Tuhan. ${ }^{45}$ Ketiga, terjadi pengampunan dan pemulihan hubungan. Lambat namun pasti mereka menjadi pribadi-pribadi yang lebih terbuka dan bahagia. Lagu rohani tentang kasih dan Firman tentang pengampunan dari Kristus membuat kesadaran ilahi untuk memberikan pengampuan kepada orang yang menyakiti mereka seperti orang tua dan keluarga. Selain itu mereka menjadi pribadi-pribadi yang bisa menerima kejadian masa lalu dan kegagalan yang pernah terjadi. Hal ini dapat dilihat dari sukacita dan kebahagian yang menyertai. Mereka tidak mengijinkan kehidupan mereka down dan kehilangan sukacita. Sebelumnya mereka tidak bisa bahagia, penuh dan mudah marah atau menangis kecewa. Keempat, mereka terbeban untuk merubah diri dari pasif menjadi pribadi yang aktif untuk Tuhan

42 Arozatulo Telaumbanua, "Peran Gembala Sidang Sebagai Pendidik Dalam Pertumbuhan Rohani Jemaat," FIDEI: Jurnal Teologi Sistematika dan Praktika 2, no. 2 (2019).

${ }^{43}$ Sitepu, "Urgensi Menemukan Model Pemuridan Sesuai Tipe Spiritualitas Jemaat."

${ }^{44}$ Asih Rachmani Endang Sumiwi, "Analisis Biblika Baptisan Roh Kudus Dan Penuh Dengan Roh Kudus," FIDEI: Jurnal Teologi Sistematika dan Praktika 1, no. 1 (2018): 1-20.

${ }^{45}$ Fenada Ziduhu Dakhi, "Pelayanan Musik, Pujian Dan Penyembahan Pada Ibadah Dan Kontribusinya Bagi Pertumbuhan Gereja," PROSIDING STT Sumatera Utara 1, no. 1 (2021): $138-146$. 
dan sesama. Ada yang mengambil bagian pelayanan dalam pelayanan doa, yang lain dalam pujian dan penyembahan. Pemimpin-pemimpin baru dilahirkan dalam kelas-kelas mentoring dan menjadi pribadi yang menjangkau jiwa jiwa dalam komunitas-komunitas yang ada. Kelima, menjadi pribadi-pribadi yang mendukung finansial gereja dan suka menabur. Sebelumnya mereka adalah orang yang selalu merasa kekurangan dan pelit untuk menabur guna mendukung pelayanan pekerjaan Tuhan. Ukurannya adalah keuangan gereja dalam keadaan baik. ${ }^{46}$ Keenam, tanda pemulihan diri mereka mempunyai gambaran masa depan yang jelas. Beberapa dari mereka mengambil kuliah dan menyelesaikan studi. Tercatat dari tahun 2012, melanjutkan pendidikan ke jenjang perguruan tinggi, ambil kuliah dan sudah diwisuda sekitar 300 Sarjana. Sebagian besar sudah kembali ke Indonesia dan kini bekerja sebagai guru di sekolah-sekolah, beberapa bank dan ada yang sudah jadi Pegawai Negeri Sipil. ${ }^{47}$

Memang harus diakui tidak semua jemaat Tuhan mengalami perubahan gambar diri yang maksimal. Namun musik pujian dan penyembahan dengan narasi Firman Tuhan yang masif setiap minggu selama bertahun-tahun dalam gereja Tuhan telah memberikan dampak besar untuk mengubah paradigma bahwa mereka jadi PMI bukan karena dosa dan kutuk namun semua karena rencana Allah. Awalnya mereka ada dalam titik terendah saat masuk ke Malaysia, namun strategi Musik, Pujian dan Penyembahan dalam pengajaran Firman Tuhan secara nyata dan kuat telah mengubah gambar diri mereka bukan saja di Malaysia namun itu berlangsung terus saat mereka sudah kembali ke Indonesia. Hal ini diperkuat dengan hasil penelitian Dumondor mengenai musik, pujian dan penyembahan dapat membawa setiap pribadi mengenal Kristus dan memiliki karakter Kristus. Dalam hal ini, saling menghargai, menghormati dan berbagi kasih, serta saling memotivasi untuk semakin mengenal Kristus. Di mana karakter Kristus akan muncul oleh pekerjaan Roh Kudus yang bekerja dari dalam yang memerbaharui, mengubahkan, menyucikan manusia lama menjadi manusia baru. Sehingga setiap orang yang mengikuti teladan-Nya mampu melakukan setiap perbuatan yang baik. ${ }^{48}$

\section{Simpulan}

Pemulihan gambar diri tidak didapatkan dalam durasi waktu yang singkat, namun memerlukan waktu relatif panjang dengan kualitas dan kuantitas yang terjaga dengan baik. Kelahiran baru merupakan langkah awal orang percaya masuk dalam proses pemulihan gambar diri: mengalami pembenaran (justification), pengudusan (sanctification) dan pemuliaan (glorification).

${ }^{46}$ Gultom and Ipoh, Wawancara Tidak Terstruktur.

${ }^{47}$ Ibid.

${ }^{48}$ Livie M. Dumondor and Berehme Adyatmo Purba, "Implementasi Pendidikan Musik Gereja Dalam Pembentukan Karakter Kristiani Pada Kelompok Paduan Suara Nine's Voice Sma N 9 Manado," Psalmoz: a Journal of Creative and Study of Church Music 1 (2020): 21-31. 
Gembala dan tim pujian dan penyembahan saling melengkapi dan mendukung satu dengan yang lain untuk menyajikan suatu pujian dan penyembahan yang menghadirkan suasana Ilahi yang dapat dinikmati, diajarkan dalam setiap kegiatan-kegiatan gereja, diulang-ulang di rumah, tempat kerja dan di manapun berada. Musik, pujian dan penyembahan sebagai strategi pemuridan menjadi sarana pengajaran dalam memberikan pengertian dan pengalaman pribadi perjumpaan dengan Tuhan, mendatangkan hadirat Tuhan yang membangun iman, harapan dan kasih sehingga menjadi langkah awal dalam memulihkan gambar diri PMI di Malaysia. Lirik pujian dan penyembahan yang bersumber dari kebenaran Alkitab akan berdampak kepada pengajaran yang akan menuntun umat kepada pengertian yang benar sehingga menghasilkan respon dan iman kepercayaan. Pujian dan penyembahan memiliki peranan yang penting untuk menyadarkan umat akan posisinya di dalam Kristus dan menyadarkan akan dosa, sehingga bertobat dan berbalik kepada jalan Tuhan, jemaat menemukan keselamatan, sehingga gambar dirinya dapat dipulihkan dan kembali kepada panggilan ilahi, menjadi lebih dewasa serta mempunyai mentalitas Surga di kehidupan sehari-hari yaitu hidup menjadi berkat bagi orang-orang di sekitar mereka.

\section{Daftar Pustaka}

Akbar, Taufan Herdansyah, Suwarti Sari, and Aliesa Amanita. "Implementasi Kebijakan Pemerintah Dalam Perlindungan Tenaga Kerja Wanita (TKW) Studi Kasus : TKW Di Malaysia.” Dinamika Global 2, no. 1 (2017): 23-47. Arlansyah, Ade Endy. "Analisis Bentuk Dan Variasi Melodi Symphony No.9 In

E Minor IV: Allegro Con Fuoco Karya Antonin Dvorak." Repertoar 1, no. 2 (2021): 226-245.

BP2MI. Data Penempatan Dan Perlindungan PMI Periode Januari 2021. Jakarta, 2021.

D., Handi Irawan, and Bambang Budijanto. Kunci Pertumbuhan Gereja Di Indonesia - Menyingkap Faktor Pendorong Pertumbuhan Gereja Berdasarkan Temuan Survei Nasional BRC. Yayasan Bilangan Research Center, 2021.

Dakhi, Fenada Ziduhu. "Pelayanan Musik, Pujian Dan Penyembahan Pada Ibadah Dan Kontribusinya Bagi Pertumbuhan Gereja." PROSIDING STT Sumatera Utara 1, no. 1 (2021): 138-146.

Darmawan, I Putu Ayub. "Jadikanlah Murid: Tugas Pemuridan Gereja Menurut Matius 28:18-20." Evangelikal: Jurnal Teologi Injili dan Pembinaan Warga Jemaat 3, no. 2 (July 2019): 144.

Dumondor, Livie M., and Berehme Adyatmo Purba. "Implementasi Pendidikan Musik Gereja Dalam Pembentukan Karakter Kristiani Pada Kelompok Paduan Suara Nine's Voice Sma N 9 Manado." Psalmoz: a Journal of Creative and Study of Church Music 1 (2020): 21-31. 
Gultom, Joni, and Jemaat BCM Ipoh. Wawancara Tidak Terstruktur. Ipoh, 2021.

Khoiriyah, Niswati, and Syahrul Syah Sinaga. "Pemanfaatan Pemutaran Musik Terhadap Psikologis Pasien Pada Klinik Ellena Skin Care Di Kota Surakarta." Jurnal Seni Musik 6, no. 2 (2017): 81-90.

Maksum, Ali. "Tenaga Kerja Indonesia (TKI) Dan Hubungan IndonesiaMalaysia Era Jokowi." Jurnal PIR 2, no. 1 (2017): 1-22.

Marisi, Candra Gunawan. "Esensi Kemanusiaan Menurut Gambar Dan Rupa Allah." Real Didache: Jurnal Teologi Dan Pendidikan Agama Kristen 2, no. 2 (2017): 5-33.

Marisi, Candra Gunawan, Didimus Sutanto, and Ardianto Lahagu. "Teologi Pastoral Dalam Menghadapi Tantangan Kepemimpinan Kristen Di Era Post-Modern: Tinjauan Yesaya 40:11.” Diegesis: Jurnal Teologi Kharismatika 3, no. 2 (2020): 120-132.

Nainggolan, Dapot. "Kajian Teologis Terhadap Musik Gerejawi." Jurnal Luxnos 6, no. 1 (2020): 32-52.

Nainupu, Marthen. "Pemuridan Melalui Pendekatan Konseling Pastoral." Jurnal Theologia Aletheia 19, no. 12 (2017): 91-140.

Nainupu, Melben, Ahmad Tabrani, and Frets Keriapy. "Pemuridan Sebagai Upaya Menanamkan Iman Kepada Kristus Pada Mahasiswa Stak Terpadu Pesat Salatiga." VOX DEI: Jurnal Teologi dan Pastoral 1, no. 2 (2020): 104-117.

Nugroho, Yahya Fajar Edhi, Yanto Paulus Hermanto, and Rubin Adi Abraham. "Program SMK ( Saya Murid Kristus ) Sebagai Pendekatan Yang Menguatkan Panggilan Dalam Amanat Agung Di Gbi Bethel Bandung." Setiadharma: Journal PKM 1, no. 44-52 (2020).

Panjaitan, Firman, and Marthin Steven Lumingkewas. "Ibadah Jemaat Kristen

Kontemporer Abad 21 Dan Tinjauan Kritis-Liturgis." FIDEI: Jurnal Teologi Sistematika dan Praktika 2, no. 1 (2019): 159-182.

Panuntun, Daniel Fajar, and Eunike Paramita. "Kaderisasi Pemimpin Melalui

Pemuridan Kontekstual Sebagai Jawaban Dari Krisis Keteladanan Kepemimpinan." KINAA: Jurnal Kepemimpinan Kristen dan Pemberdayaan Jemaat 1, no. 1 (2020): 1-15.

Pram. "Pemuridan Mempengaruhi Pertumbuhan Rohani." Berita Bethel.

Purnomo, Edi, Akbar Nur, Rachmawati Rahim, Zulhaini Sartika, and A Pulungan. "The Effectiveness of Instrumental Music Therapy and SelfHypnosis on Decreasing Blood Pressure Level among Hypertension Patients." International Journal of Nursing and Health Services (IJNHS) 3, no. 2 (2020): 214-223.

Salim, Djohan. Terapi Musik: Teori Dan Aplikasi. Yogyakarta: Galang Press, 2006.

Shaleha, Rinanda Rizky Amalia. "Do Re Mi: Psikologi, Musik, Dan Budaya." 
Buletin Psikologi 27, no. 1 (2019): 43.

Sirait, Bigman. "Ritual Tanpa Spritual." Reformata.

Sitepu, Nathanail. "Urgensi Menemukan Model Pemuridan Sesuai Tipe Spiritualitas Jemaat." HARVESTER: Jurnal Teologi dan Kepemimpinan Kristen 5, no. 2 (2020): 105-119.

Sitompul, Putra Hendra S. "Musik Dalam Dinamika Pujian Penyembahan." PNEUMATIKOS: Jurnal Teologi Kependetaan 10, no. 2 (2020): 176-199.

Suhartoyo, Suhartoyo. "Prinsip Persiapan Penempatan Dan Perlindungan

Tenaga Kerja Indonesia Di Luar Negeri." Administrative Law and Governance Journal 2, no. 3 (2019): 523-540.

Sumiwi, Asih Rachmani Endang. "Analisis Biblika Baptisan Roh Kudus Dan Penuh Dengan Roh Kudus." FIDEI: Jurnal Teologi Sistematika dan Praktika 1, no. 1 (2018): 1-20.

Telaumbanua, Arozatulo. "Peran Gembala Sidang Sebagai Pendidik Dalam Pertumbuhan Rohani Jemaat." FIDEI: Jurnal Teologi Sistematika dan Praktika 2, no. 2 (2019).

Wijaya, Hengki. "Kajian Teologis Tentang Penyembahan Berdasarkan Injil Yohanes 4:24." Jurnal Jaffray 13, no. 1 (2015): 77.

. "Metode-Metode Penelitian Dalam Penulisan Jurnal Ilmiah Elektronik." In Strategi Menulis Jurnal Untuk Ilmu Teologi, edited by Sonny Eli Zaluchu, 23-42. Semarang: Golden Gate Publishing, 2020. 